\title{
A Study of Formal Links Used in English Translation of Hadith Muslim by Abdul Hamid Siddiqui
}

\author{
M. Arsal Hijaz ${ }^{1^{*}}$ \\ ${ }^{1}$ Department of English Language Studies, Universitas Hasanuddin, Makassar, Indonesia \\ *arsalhijaz@gmail.com
}

\begin{abstract}
This study analyzed the types of formal links and the functions of formal links in the hadith Muslim to describe the types of formal links used in the English translation of hadith Muslim and describe the functions of formal links functions in the hadith Muslim. It used a descriptive qualitative research method in which the data are taken from the text of English translation of hadith Muslim. The findings show all types of formal links: verb form, parallelism, referring expression, repetition, substitution, ellipsis, and conjunction. From those findings, the theory of Guy Cook on the formal link is expected to contribute to readers who have difficulties understanding some text and make a good text a lot easier. This research is helpful for teachers, students, and all English learners who are intensely constructing their ability to know formal links in writing. And for further research, it would be better to use a different focus theory and be more interesting as the object of the study.
\end{abstract}

Key words: Formal links, English translation, Hadith Muslim, The Book of Marriage.

\section{Introduction}

Discourse analysis concerned with the use of language in a running discourse, continued over a number of sentences involving the interaction of speaker (or writer) and auditor (or reader) in a specific situational context, and within a framework of social and cultural conventions [1]. Discourse analysis aims to isolate units of text which are distributional equivalent though not necessarily similar in meaning, that is equivalences which have validity for the translator. It focuses on correct grammar to build the relation between word, phrase, clause, sentence and paragraph of the source text, and also language-users interpreting what other language-users intend to convey. The translated text attempts to arrive at a reasonable interpretation of what the writer intended to convey. It is this effort to interpret (and to be interpret), and how we accomplish it, that are the key elements investigated in the study of discourse, "To arrive at an interpretation, and to make our message interpretable, we certainly rely on what we know about linguistic form and structure" [2].

This study focuses formal links analysis on the translation texts using formal links to avoid misunderstanding in written text especially in the English translation of Hadith. Formal links are the important devices that are used to connect sentences in a text. These devices help the readers understand texts easily. Formal Link between sentences or clauses is known as cohesive devices. Each cohesive device type consists of several subtypes. Formal links include: 
verb form, parallelism, referring expressions, repetition and lexical chains, substitution, ellipsis, and conjunction [3]. Therefore, it is important to know the kind of formal links and how to use them correctly in making the unity of the text. In approaching language it is not as easy as it looks, it is not simply sequences or utterances the form by which sender communicates a message to a receiver (the function) [4]. Contextual features are somewhere outside this physical realization of the language. Formal links of Cook's theories are the parts of unity of discourse analysis. Some researchers have examined about several of formal links, for instance: Ghozali, his research focused on analyzing a short story [5] and Maharlika, the study of Cook's theories include all the types of formal links, the object of her research is English translation Sahih Bukhari [6].

There are many rules settled from a variety of conditions, "Hadith" is one of the various reports describing the words, actions, or habits of the Islamic prophet Muhammad [7]. The difference between this study and the previous studies, the study analyses all Muslim hadith about marriage in Siddique translation. He evaluated more than 300,000 hadiths and approximately 4,000 were extracted for inclusion into his collection based on stringent acceptance criteria. The study is limited in analyzing the book of marriage, because it is usually difficult to get the message, because of the differences in language between Arabic and English. There are Arabic words that cannot be translated into English. Because of that, formal links theory can help to avoid the misunderstanding between sentences of the texts. It is very important to be known by people all over the world about Marriage in some problems and any conditions of the translation.

\section{Methodology}

This study applies the descriptive qualitative method; observing, selecting, coding, and classifying the object to find out formal links implementation in English translation Hadith Muslim. Qualitative research is concerned with structures and patterns, but quantitative research focuses on how much or how many there are of a particular characteristic or item [8]. The data are taken from the text hadiths in Sahih Muslim that are collected from various kinds of internet resources and limited only analyzing the Hadith English Translation of chapter the book of marriage [9]. This study adapted Cook's theory that is divided into some sub-devices categories i.e., Verb Form, Parallelism, Referring expression, Repetition/lexical chain, Substitution, Ellipsis, and Conjunction.

The data analysis is interpreting the function used in formal links. The steps to be taken are as follows: 1) Collecting the data which is in the form of the written text of Hadiths English translation by Siddiqui and reading the Hadiths English translation. 2) Select Hadiths in The Book of Marriage because the Hadith in this chapter has more variation of formal links. 3) Giving codes to the words or sentences in the text Hadith that are contained of formal link based on Cook's theory of cohesion device that divided into 7 categories: Verb Form, Parallelism, Referring expression, Repetition/lexical chain, Substitution, Ellipsis, and Conjunction. It is directly involved in observing, selecting, coding, and classifying the object. Among all the formal links used, this study analyzed their functions. The model of formal links used in the study is also the focus of this study.

\section{Findings and Discussion}

There are twenty sub-topics translated texts are selected into twenty data in the English translation book of marriage Hadith Muslim. As formulated in the purpose of this study, two topics types and functions are presented in this part simultaneously of each data in the translation of Hadith Muslim includes all the data that are used in the research to analyze the formal links. The sentences that contain formal links, it is helping the readers easily find the texts.

\section{Types and functions of formal links in data 1}

\section{Verb Form}

Datum 1: "Alqama reported: While I was walking with 'Abdullah at Mina, 'Uthman happened to meet him. He stopped there and began to talk with him".

In the hadith above there are different verb forms. The first verb form is past continuous and the second verb form is simple past tense. Verb form on the first sentence limits the choices on the second verb form because the subject in the first sentence described "was walking" and in the second-mentioned that the subject already does not have another option and has to "stop".

\section{Referring Expression}

Datum 2: "Alqama reported: While I was walking with 'Abdullah at Mina, 'Uthman happened to meet him (1). He stopped there and began to talk with him (2), Uthman said to him (3): Abu 'Abd al-Rahman, should we not marry you to a young girl who may recall to you some of the past of your bygone days".

The words "he", "him (1)", "him (3)", "you", and "your" referred to a person Abu 'Abdullah al-Rahman and word "him (2)" as a pronoun of "Uthman, their names are mentioned earlier of the sentence. It is called anaphora 
expression because the identity of someone or something is given once at the beginning and thereafter followed by the pronoun.

\section{Combined Theme Pattern (Multiple)}

Datum 3: "Uthman said to him: Abu 'Abd al-Rahman, should we not marry you to a young girl who may recall to you some of the past of your bygone days; thereupon he said: If you say so,"

The substitution happens here because the word "so" substitutes the representation of marry you to a young girl who may recall to you some of the past of your bygone days. It is a short sentence but the reader or listener understands. The usage of the word "so" used to express an action of deciding or allowing something.

\section{Conjunction}

Datum 4: "While I was walking with 'Abdullah at Mina, 'Uthman happened to meet him. He stopped there and (1) began to talk with him. Uthman said to him: Abu 'Abd al-Rahman, should we not marry you to a young girl who may recall to you some of the past of your bygone days; thereupon he said: If you say so, Allah's Messenger (may peace be upon him) said: 0 young men, those among you who can support a wife should marry, for it restrains eyes from casting (evil glances), and (2) preserves one from immorality; but those who cannot should devote themselves to fasting for it is a means of controlling sexual desire".

The conjunction is found 'and (1)' and 'and (2)' used to add more details information, conjunction 'and (1)' also tells about the steps act occurred before Uthman talk with 'Abdullah, while conjunction 'but' here used for show exemption or commitment for those among you who can support a wife should marry and those who cannot. The usage conjunction 'thereupon' shows the information of Abdullah's words from Uthman. Therefore, the conjunction used in the sentence to make relation one to another, in giving information of a responsible.

\section{Types and functions of formal links in data 2}

\section{Verb Form}

Datum 5: "He (the Holy Prophet) praised Allah and glorified Him, and said: What has happened to these people that they say so and so, whereas I observe prayer and sleep too; I observe fast and suspend observing them; I marry women also? And he who turns away from my Sunnah, he has no relation with $M e^{\prime \prime}$.

In the hadith above there are two similar verb forms that are present tense. However, the two verb forms have two different functions in which the verb form "has no" is an affirmation of the consequences if it violates the rules, in this case emphasized using the verb form "turns away".

\section{Paralleism}

Datum 6: "Someone among them (among his Companions) said: I will not marry women; someone among them said: I will not eat meat; and someone among them said: I will not lie down in bed".

Grammatical parallelism is a device which suggests a connection. The hadith above employs parallelism to link clauses as there is a repeated grammatical structure (I will not....). This proceeds through a repeated grammatical structure into which different words are slotted.

\section{Referring Expression}

Datum 7: "Anas (Allah be pleased with him) reported that some of the Companions of Allah's Apostle (may peace be upon him) asked his (the Prophet's) wives about the acts that he performed in private".

The word "his" in this sentence refers to the Prophet's wives as the identity of someone is given after the pronouns known as cataphoric expressions. This makes a kind of chain running through the discourse, in which each expression is linked to another. Like the writer stated before, that the anaphora is to identify someone or something to be given once at the beginning and thereafter referred to as a pronoun. The word "he" refers to the Prophet that is used to make clearer information.

\section{Repetition and Lexical chain}

Datum 8: "Someone among them (among his Companions) said: I will not marry women; someone among them said: I will not eat meat; and someone among them said: I will not lie down in bed".

Here the clauses are linked through the repetition of 'someone among them' repeated three times used to indicate there are different people who say that from each repetition. Sometimes is often used rather than to refer to pronouns and it helps to focus the ideas and to keep your reader/listener on track.

\section{Substitution}

Datum 9: "He (the Holy Prophet) praised Allah and glorified Him, and said: What has happened to these people that they say so and so" 
The word 'so' substitutes for a word or group of words which have appeared in an earlier sentence. The usa of the word say so and so may make a short sentence in one conversation.

\section{Conjuction}

Datum 10: "He (the Holy Prophet) praised Allah and glorified Him, and said: What has happened to these people that they say so and so, whereas I observe prayer and sleep too; I observe fast and suspend observing them; I marry women also? And he who turns away from my Sunnah, he has no relation with Me".

Use of the 'whereas' shows to place the other side of the given argument. One thing happened besides something else. The use of conjunction 'and' to connect two phrases into a sentence. Therefore, the conjunction used in the sentence to make a relation one to another.

Types and functions of formal links in data 3.

\section{Verb Form}

Datum 11: "Allah's Messenger (may peace be upon him) forbade him to do so, and if he had permitted him, we would have got ourselves castrated".

It can be seen from the hadiths above that there are two verb forms. The first verb form 'had permitted' is past perfect tense and the other verb form 'would have got' is past future perfect. Hence the sentence is narrative past tense and narrated by Sa'd b. Abi Waqqas. The two verb forms interfere with each other, in which the first verb form is 'had permitted ' gives a limit to the second verb form.

\section{Referring expression}

Datum 12: "Sa'id b. al Musayyib heard Sa'd b. Abi Waqqas (Allah be pleased with him) saying that Uthman b. Maz'un decided to live in celibacy, but Allah's Messenger (may peace be upon him) forbade him to do so, and if he had permitted him, we would have got ourselves castrated".

The meaning of 'him' is referred to Uthman b. Maz'un, as the identity of someone is given earlier in the paragraph. Meanwhile, the meanings of 'he' refer to Allah's Messenger (may peace be upon him) as the identity of someone is given after 'Uthman. From the above explanation, all of the referring expressions in this hadith belong to the anaphoric category, because anaphoric referring expression is a pronoun that expresses someone or something is given once at the beginning.

\section{Substitution}

Datum 13: "Sa'id b. al Musayyib heard Sa'd b. Abi Waqqas (Allah be pleased with him) saying that Uthman b. Maz'un decided to live in celibacy, but Allah's Messenger (may peace be upon him) forbade him to do so".

Here "so" substitutes the underlined sentence that has appeared earlier, it substitutes the arguments about "Uthman wants to do celibacy. In this case, the word "so" substitutes a group of words or sentences.

\section{Conjunction}

Datum 14: "Sa'id b. al Musayyib heard Sa'd b. Abi Waqqas (Allah be pleased with him) saying that Uthman b. Maz'un decided to live in celibacy, but Allah's Messenger (may peace be upon him) forbade him to do so, and if he had permitted him, we would have got ourselves castrated".

The word 'but' here as the conjunction shows the exemption of permission. While, conjunction 'and' in that hadith to connect one idea into others

\section{Types and functions of formal links in data 4}

\section{Verb Form}

Datum 15: "The woman advances and retires in the shape of a devil, so when one of you sees a woman, he should come to his wife, for that will repel what he feels in his heart".

The first verb form 'will repeal' is future and the second verb form 'feels' is present. In the first verb form is the exposure as a result that may occur which then described in the second verb form is feeling in the present form "feels" in this case feeling of men.

\section{Referring Expression}

Datum 16: "Jabir reported that Allah's Messenger (may peace be upon him) saw a woman, and so he came to his wife, Zainab, as she was tanning a leather and had sexual intercourse with her".

The word 'he' and 'his' occurs after Allah's Messenger (may peace be upon him) as the identity of someone is given at the beginning. While 'she' and 'her' refer to Zainab as the identity of the wife. This makes a kind of chain running through the discourse, in which each expression is linked to another. 


\section{Conjuction}

Datum 17: "Jabir reported that Allah's Messenger (may peace be upon him) saw a woman, and so he came to his wife, Zainab, as she was tanning a leather and had sexual intercourse with her".

From hadith above, we can see that the word 'so' shows cause and effect. The cause is that Allah's Messenger (may peace be upon him) saw a woman. And the effect is he came to his wife, Zainab, as she was tanning a leather and had sexual intercourse with her. Conjunctions which are stated with 'and' appear in two times used in the hadith to make a relation. In a sentence, there must be one topic discussed with any explanation in each paragraph.

\section{Types and functions of formal links in data}

\section{Parallelism}

Datum 18: "One should not combine a woman and her father's sister, nor a woman and her mother's sister in marriage".

The hadith above employs parallelism to link clauses as there is a repeated grammatical structure ( $a$ woman and her......sister). The use of parallels here shows the relation as they reveal the same meaning that is a woman and an aunt.

\section{Conjunction}

Datum 19: "One should not combine a woman and her father's sister, nor a woman and her mother's sister in marriage".

The conjunction in hadith above is only single time that is the word 'nor'. The usage of conjunction 'nor' shows contrast new additive information with old information.

Types and functions of formal links and in data 6

\section{Referring Expression}

Datum 20: "Allah's Apostle (may peace be upon him) married Maimuna in the state of Ihram. Ibn Numair made this addition:" I narrated it to Zuhri and he (1) said: Yazid b. al-Asamm (Allah be pleased with him) told me that he (2) (the Holy Prophet) married her when he (3) was not a muhrim."

The use of 'it' as pronoun is identified from the narration of Ibn Abbas which has been underlined in the hadith. The representation of the narrative by Ibn Abbas with the pronoun 'it' to make clearer explanation about the condition when Allah's Apostle (may peace be upon him) married Maimuna in the state of Ihram, so this is categorized into anaphora. Still one sentence, the pronoun 'he (1)' and 'me' refer to Zuhri. The pronoun 'her' identified as Maimuna. The word 'he (2)' and 'he (3) identified as the Holy Prophet. So, the word 'he (1)', 'he (3)', 'me', and 'her' as the pronoun is given first identity earlier, it is called anaphora. At the same time the Holy Prophet is given after 'he (2)' as pronoun, so this one is categorized into cataphora.

\section{Types and functions of formal links in data 7}

\section{Parallelism}

Datum 21: "None amongst you should outbid another in a transaction, nor should he make proposals of marriage upon the proposal made by someone else".

The above hadith are connected as they reveal the same thing. In this case, the sentences are linked because it has the same things. So, a device to suggest a connection is called semantic parallelism.

\section{Conjuction}

Datum 22: "None amongst you should outbid another in a transaction, nor should he make proposals of marriage upon the proposal made by someone else".

The word 'nor' used before the second or further of two or more alternatives, the first being introduced by a negative None amongst you indicate that they are each untrue or each do not happen.

\section{Types and functions of formal links in data 8.}

\section{Verb Form}

Datum 23: "Shighar means that a person should say to the other person: Give me the hand of your daughter in marriage and I will (in return) marry my daughter to you; or merry me your sister, and I will marry my sister to you".

There are two Verb forms in the hadith above. Those verb forms are 'give' and 'will marry'. The first form 'give' is a present tense, which implies an offering as a result of the second verb form "will marry". There is a degree of formal connection between them. 


\section{Parellism}

Datum 24: "Give me the hand of your daughter in marriage and I will (in return) marry my daughter to you; or merry me your sister, and I will marry my sister to you".

In the hadith above two sentences are linked as both of the sentences reveal the same thing that Give me yours and I will give mine to.

\section{Referring Expression}

Datum 25: "Shighar means that a person should say to the other person: Give me the hand of your daughter in marriage and I will (in return) marry my daughter to you; or merry me your sister, and I will marry my sister to you".

The word 'I', 'me', and 'my' in the above hadith represent a person who has mentioned an earlier sentence. While the word 'you' and 'yours' represents the other person that mentioned previously. The referring expression category here is anaphoric, because the identity is mentioned at the beginning before the pronoun.

\section{Conjuction}

Datum 26: "Shighar means that a person should say to the other person: Give me the hand of your daughter in marriage and I will (in return) marry my daughter to you; or merry me your sister, and I will marry my sister to you".

In the above hadith, there are two words 'and' conjunctions found to connect two phases into one sentence. And conjunctions with the word 'but' found to connect the sentences into one topic of discussion. However, conjunctions are used in sentences to connect to one another, providing more specific information about the character of the daughter and sister.

\section{Type and functions of formal links in data 9}

\section{Verb Form}

Datum 27: "'A'isha reported: I told him that she feels shy, whereupon Allah's Messenger (may peace be upon him) said: Her silence implies her consent".

The hadith above shows the difference from the use of each verb form. In the first sentence, there are two verb forms are "told" is past tense and "feels" is present. Both sentences in the hadith above have the same meaning but these sentences are delivered with different sentence forms and different verb forms. In the second sentence "implies", the verb form used is a simple present, it is different from the first sentence using present tense and past tense.

\section{Referring Expression}

Datum 28: "I asked Allah's Messenger (may peace be upon him) about a virgin whose marriage is solemnised by her guardian, whether it was necessary or not to consult her".

The pronoun 'her' in the hadith above appears two times which refers to a virgin. While, the word 'it' represents solemnisation. Both the pronoun in the hadith above has mentioned earlier identity, which means categorized as referring to anaphoric expression.

\section{Conjunction}

Datum 29: "I asked Allah's Messenger (may peace be upon him) about a virgin whose marriage is solemnised by her guardian, whether it was necessary or not to consult her".

In the hadith above, there are two conjunctions found, the word 'whether' used especially in reporting questions and expressing doubts about a virgin whose marriage is solemnised by her guardian. The word 'or' used to connect different possibilities necessary or not.

\section{Types and functions of formal links in data 10}

\section{Referring Expression}

Datum 30: "'A'isha (Allah be pleased with her) reported: Allah's Messenger (may peace be upon him) married me when I was six years old, and I was admitted to his house at the age of nine".

We can see there are two pronouns 'me' and 'his' in the hadith above. The word 'me' clearly refers to Aisha who narrated the hadith herself. The word 'his' represents Allah's Messenger (may peace be upon him) identified in the earlier sentence, so both of the words' referring expressions can be categorized into anaphoric expressions.

\section{Ellipsis}

Datum 31: "She took hold of my hand and took me to the door"

In this sentence, there is an omission. She took hold of my hand and (she) took me to the door. The omitting (she) here keeps making clear sentences. 


\section{Conjunction}

Datum 32: ''A'isha (Allah be pleased with her) reported: Allah's Messenger (may peace be upon him) married me when I was six years old, and I was admitted to his house at the age of nine. She further said: We went to Medina and I had an attack of fever for a month, and my hair had come down to the earlobes".

In the hadith above, the word conjunction 'further' is used to bring the explanation of Allah's Messenger (may peace be upon him) married me when I was six years old, and I was admitted to his house at the age of nine to a more detailed stage.

There are seven types of formal link analyzed in this study presents the in table as follows:

Table 1. Types of Formal Links

\begin{tabular}{llc}
\hline No & Type of formal links & Amount of formal links \\
\hline 1 & Verb form & 6 data \\
2 & Parallelism & 4 data \\
3 & Referring Expression & 8 data \\
4 & Repetition and Lexical Chain & 1 data \\
5 & Substitution & 3 data \\
6 & Ellipsis & 1 data \\
7 & Conjunction & 8 data \\
\hline
\end{tabular}

From all of the explanations above, the function of formal links which were found includes verb form in one sentence and can limit the text in the next sentence [3]. There seems to be a degree of formal connection between them in a way of consistency in using certain tenses. For parallelism is to simply the language that is used, for referring expression is to indicate reference pronoun. For repetition is to stress the text idea, for substitution and ellipsis are to make this utterance accurate. And for conjunction is to indicate cause and effect relation, to indicate comparison and contrast in hadith. The analysis was done based on the place of formal links in the English translation of hadith Muslim by Abdul al-Hamid Siddiqui. Therefore, there are several functions of conjunction which are different from each other depending on the types of conjunction such as to indicate cause and effect, adding more information, illustrating the term of time, etc.

\section{Conclusion}

In the end of this study, formal links are divided into seven aspects. The kinds of formal links consist of verb form, parallelism, referring expressions, repetition and lexical chains, substitution, ellipsis, and conjunction. Parallelism is a device which suggests a connection; it is used to provide a powerful emotional effect. Parallelism is divided into three types namely, grammatical parallelism, sound parallelism, and semantic parallelism. Grammatical parallelism proceeds through a repeated grammatical structure [3]. Semantic parallelism happens when the sentences are linked because they mean the same thing. Referring expressions mostly used in hadith, it occurs in every paragraph. Referring expressions mean words of the meaning can only be discovered by referring to other words or elements of the context which are clear to both sender and receiver, referring expressions indicate referring pronouns also save us from repeating the identity that is already given again and again. There are three types of referring expressions, namely anaphoric referring expressions, cataphoric referring expressions, and exophoric referring expressions. Anaphoric found in all pages in the hadith, it indicates the identity of someone or something that was already given once at the beginning, and thereafter referred with pronouns. Cataphoric found only some in a specific paragraph. Exophoric was not found in hadith. Next, repetition is found just for stressing some points and keeps the reader/listener on track.

Substitution and ellipsis found in the text hadith to make the hadith efficient and simpler to understand. Furthermore, a conjunction is found quite in the hadith. A conjunction like (so, because, consequently, for this reason, etc.) occurs in the hadith, it is giving cause and effect relating new information to what has already been given. A conjunction such as (or, on the other hand, etc.) occurs in the hadith, it is used for contrasting new information with old information. A conjunction like (formerly, then, in the end, etc.) occurs in the hadith, it is used for illustrating terms of time. A conjunction such as (furthermore, in addition, moreover, etc.) occurs in the hadith, it is used for adding more information to what has already been said. Overall, referring expressions are mostly used in the English translation of Hadith by Abdul al-Hamid Siddiqui. One of the types of referring expressions is anaphoric that the most often in the hadith above. Meanwhile, sound parallelism and exophoric referring expressions do not occur in the hadith, because most of them appear in poetries 


\section{References}

[1] M. H. Abram, \& G. G. A. Harpham, Glossary of literary terms, $9^{\text {th }}$ ed. Boston: Wardworth Cengage Learning, 2005.

[2] G. Yule, The study of language. Cambridge, UK: Cambridge University Press, 1985.

[3] G. Cook, Discourse, $3^{\text {rd }}$ ed. Oxford University Press, 1989.

[4] J. Renkema, Discourse Studies: An introductory textbook, $2^{\text {nd }}$ ed. Amsterdam, Philadelphia: John Benjamins, 1993

[5] F. Ghozali, "A Study of formal links in Willa Carther's Birthday" Undergraduate thesis, University of Sunan Ampel, Surabaya, 2016.

[6] N. Maharlika, "An Analysis of Formal Links Used in the English Translation of Shahih Bukhari, Maulana Malik Ibrahim" Graduate thesis, The State Islamic University of Malang, Malang, 2010.

[7] E. J. Campo, Encyclopedia of Islam. New York, FOF: An imprint of InfoBase publishing, 2009.

[8] L. Litosetti, Research methods in linguistics. London: Continuum, 2010.

[9] A. H. Siddiqui (2009), Hadith Muslim: chapter the book of marriage [Online]. Available https : //www. sunnah. $\mathrm{com} / \mathrm{muslim} / 16$ 